\title{
Elements of pathos and media framing as scientific discourse: A newspaper perspective on Rohingya crisis
}

\author{
Naeem Afzal* \\ Department of English, College of Sciences and Humanities, Prince Sattam Bin Abdulaziz University, Saudi Arabia
}

\section{A R T I C LE IN F O}

\section{Article history:}

Received 3 June 2016

Received in revised form

18 October 2016

Accepted 22 October 2016

\section{Keywords:}

Rohingya crisis

Newspaper editorials

Framing strategy

Emotions

\begin{abstract}
A B S T R A C T
Media framing should remain a legitimate device of social criticism and an aid to people's decision making by an influence on their perceptions about a given issue or a social crisis. Ever since the Rohingya crisis erupted as a human rights issue, media has framed this crisis with different perspectives : a refugee crisis, a citizenship war, a political battle of survival, xenophobia, Islamophobia, anti-Muslim racism, issue of ethnic minority and similar other frames ascribed to the crisis. Media accused the government of genocide since it had refused to accept Rohingya as a historical, bi-cultural ethnic group. All such framing indicated the sole objective of refusing citizenship to the Rohingyas and resulted in significant reactions from international foraeach trying to shape the worldview about the Rohingya crisis. This research paper aims at studying framing strategy as a scientific discourse which has brought the international media stand face to face against the ruling elite of Myanmar on the Rohingya crisis. This study shall make an attempt to investigate how the editorial opinions of Pakistani, American and British mainstream newspapers covered the Rohingya Muslim crisis and to what extent kept the audience closer to the events by appealing to emotions or pathos. Through a scientific content analysis, this research explores how the Buddhists/Brumes government's treatment of Rohingya crisis was portrayed by the mainstream English language newspapers in a Muslim majority country (Pakistan) and outside the Muslim world by the Western media (Britain, USA).
\end{abstract}

(C) 2016 The Authors. Published by IASE. This is an open access article under the CC BY-NC-ND license (http://creativecommons.org/licenses/by-nc-nd/4.0/).

\section{Introduction}

The Rohingya Muslims (Arakani Muslims), living in the northwestern state of Myanmar called Rakhine (Arakan), have been recognized as an indigenous Muslim ethnic group since the independence of Myanmar in 1948. In 1982, they were officially rendered stateless under the new promulgations of Citizenship Act (Letchamanan, 2013; Parnini et al., 2013). The gravity of this crisis in Burma (Myanmar) came to public view in 2012 when violence erupted leaving hundreds dead and with as many as 140,000 reportedly displaced. The Rakhine Buddhists, the ruling majority, comprise about 60 percent while the Muslims including the Rohingya are just about 30 percent of the total population. Annexation of the Rakhine state to

\footnotetext{
* Corresponding Author.

Email Address: n.awan@psau.edu.sa

https://doi.org/10.21833/ijaas.2016.10.014

2313-626X/C) 2016 The Authors. Published by IASE.

This is an open access article under the CC BY-NC-ND license

(http://creativecommons.org/licenses/by-nc-nd/4.0/)
}

British India in 1825 attracted a large number of Muslim migrants from Bengal to the region. Such migrations caused change in the ethnic and religious mix of the state, creating socio-economic problems and consequently evoking resentment from the Rakhine Buddhist community. The clashes between Muslims and Buddhists turned into violence when Muslim population supported Britain in the First World War while Buddhists supported Japan. Both the communities attacked each other with their armed units. Muslims moved to the north and the Rakhine population moved to the south of the state. This caused a segregation of Rakhine into two sections: the Muslims and Buddhists. After the country (Myanmar) got independence, the Rakhine Muslims decided to inhabit the Muslim autonomous areas as well in the north. But they faced discriminations from Buddhists officials and the immigration authorities placed restrictions on their movements. The rebels from the Rakhine Muslims attacked Buddhist interests; the government seized larger parts of northern Rakhine and expelled many villagers (International Crisis Group, 2014). 
After the military coup in 1962, the Burmese army committed frequent human rights violations, killed, raped and tortured Rohingya Muslim community. A few other instances of injustice against the Rohingya Muslims included rejection of citizenship status, employment and school admission to the children (Abdelkader, 2014). The International Crises Group (2014) also claimed that military coupe policies of 1962 denied Rohingya Muslims of citizenship and recommended harder stance. Due to lack of any formal immigration status of Muslims, the citizenship law in 1982 further eroded Muslims rights. Even the results of multiparty elections of 1990, in which several Rohingya representatives got elected, were not implemented. In the following year, 1991, military troops confiscated the Muslims land they used for agriculture and camping and imposed arbitrary taxes and forced labour on the villagers. In 2001, violence broke out between Rakhine Buddhists and Muslims in which 20 people were killed, homes and businesses torched, Muslims mosques and madrassas were destroyed. Political tensions emerged again in the 2010 multiparty elections when the Rakhine Buddhists objected to grant citizenship to Rohingya people. Such intercommunal tensions contributed to anti-Muslim violence in 2012.

Rohingyas Muslims have been officially categorized by the government as illegal immigrant from Bangladesh. On the contrary, the Rohingyas claim to be the residents of Myanmar by tracing their origin for more than a thousand year ago (Azad and Jasmine, 2013). The Rakhine Muslims have found their cultural identity under threat with increasing opposition from Buddhists who are more interested in preserving their own cultural and religious values. A state of emergency was imposed in 2012 due to high scale violence between the communities which killed and injured hundreds of people from both the communities. Thousands of homes of Rohingya Muslims were destroyed resulting in their displacement. Even, in most of the following episodes of violence, Rohingya Muslims faced more destruction and losses with increased restrictive measures placed on them. International Crises Group (2014) reports that according to UN estimates 310,000 people requiring human assistance in Rakhine State.

Chyi and McCombs (2004) argued that during any news event's life period, for instance the Rohingya crisis, the news media practice reframing the events by endorsing its various attributes "consciously or unconsciously - to keep the story in the spotlight". Even though the frames may change during the course of the framing of that event, in the context of Rohingya crisis our aim is to investigate whether or not the frames favor one side of the crisis. It is therefore required to study how far the Western newspapers narrated the Rohingya Muslim crisis in comparison with the newspaper coverage of the events in a Muslims majority country (Pakistan). In the context of Rohingya Muslims crisis, since it has taken a very long period of four decades, we may like to refer to Chong and Druckman, (2007) who explained the concept of framing as the process by which people build a particular perception about an issue or reestablish their beliefs about an issue over a period of time. They also argued that framing process is also utilized by media as a means to define issues for the public. Chong and Druckman also argued that a framing effect takes place when individuals arrive at certain positions about the conflict based on certain considerations which are given priority over others. For instance, a newspaper editorial which defends a particular group voice consequently moves the readers to focus more on the desired concerns.

\section{Media framing}

The term "framing" has been commonly used in diverse fields like sciences, psychology, communication, sociology or management. The term framing, like other concepts related to mass communication research, has been used in by media scientists, media critics and politicians. For instance, Noam Chomsky (1990) used this term during an interview describing that The New York Times story framed a deal made by Iraq to withdraw from Kuwait. In relation to the news coverage of this event of 1990, the term frame was used excessively in media and political arenas to refer to Kuwaiti crisis. Media framing is significant because it serves as an alternative to "objectivity and bias paradigm", it assists in perceiving wider effects of mass communication. Framing oversteps favourable or unfavourable notions and involves complex emotional responses and cognitive dimensions which include beliefs and attitudes (Tankard, 2001), as the case of Rohingya conflict erupted between the Muslims minority and Buddhist majority.

Media framing originates when there is a need to give prominence to a certain component of a news event or a crisis (De Vreese, 2003) which may have a positive, negative, or neutral acceptance from the readership. Such media frames are constructed on a news story that cater to readers' understanding of their thought about political, economic, and social topics (De Vreese et al., 2001). Moreover, there are several corresponding media frames when portraying an event. A journalist, for example, has his individual frame (level of cognition), who interacts with group frames in with fellow colleagues (level of discourse), exchanges views with other media discourses in order to influence news coverage (level of discourse product) (Scheufele, 2004). Moreover, framing theories have suggested that news coverage bring changes in public opinions as it promotes particular definitions and explanations of political issues (Shah et al., 2002). Entman (2004) defines framing as the process of removing a few ingredients of observed reality and aggregating a story that highlights relations among them to provide a specific explanation while according to another view, frames stress upon 
reality and point towards certain judgments, decisions and attributes (Lecheler et al., 2013).

Framing mirrors the diversity of media discourse and such fine differences that possibly emerge when a particular issue is described through different ways. These fine points are often lost if a "crude proor-con bias" approach is adopted. Nonetheless, this subtleness also makes framing hard to explain. Media framing is vital because it can have subtle but influential effects on the audience, even to the point of helping to overthrow a president of a country. The study of media framing can assist individuals identify and examine vital points in the opinion change process where these influential effects are taking place. Most of the framing power comes from its capability to explain the terms of an issue without the audiences realizing it is happening. Framing can be better understand through the analogy magician's sleight in which hand-attention directs to one side so that people do not observer the manipulation which works on the other side. The concept of framing is also important because it provides new visions and influence points for communication practitioners, including journalists, planners of communication movements, and social campaigners (Tankard, 2001).

The concepts of framing and frames have attracted numerous research scholars in varied range of disciplines for studying conflicts such as the Rohingya Muslim conflict. According to Dewulf et al. (2009) the renaissance of interest in in frames and framing has generated a number of definition for these concepts and even caused confusion among the researcher who use define, use and operationalize these definitions. Van Group (2007) argued that during the last few years, framing theory has surpassed agenda-setting and cultivation theory and has emerged as the most common form of applied research in the field of communication. In addition, a frame is rated effective if it influences public opinion. A frame in mass communication or media frame represents words, phrases or presentation styles which are used by media outlets such as newspapers when sharing information with an audience about an event. On the contrary, an individual frame or frame in thoughts means the cognitive understanding of an individual (reader) as what he considers the salient features of an issues being an audience member (Chong and Druckman, 2007). According to Scheufele and Tewksbury (2007) framing is based on the postulation that how an event is described in the news media can affect how it is perceived by the audience.

Media frames influence public opinion (Lecheler, 2010) but depends on how elites frame issues (Chong and Druckman, 2007). The audience is also guided by frames in making sense of complex situation in a manner which is internally relevant to our views about the world. Frames also help us in giving meaning to events in real contexts and understandings. Frames are also considered cognitive devices by most researchers for understanding complex information. Such cognitive constructions are used to simplify high amounts of information. Frames thus, serve as filters to individuals' insights, influence them and organize any particular phenomenon into understandable categories (Shmueli et al., 2006). As argued by Dewulf et al. (2009) frame are cognitive representation of knowledge which is stored in memory and then recovered and used in new conditions. Frames can be differentiated between cognitive and interactional. The cognitive approach concentrates on memory structures, which guarantees that incoming perceptual information fits into prebuilt fantasy about reality. Converse to this, the interactional approach is a more active process within a negotiation, an argument. Therefore, the frame has to be accommodating through the whole. Thus it could be said that cognitive frames or knowledge schemes are related to constructions of anticipations about people, objects and setting, while interactive frames focus on alignments and communication within an interaction (Dewulf et al., 2009). De Vreese (2005) pointed out that news frame can be defined and understood as "a story line that provides meaning to an unfolding strip of events". Another purpose of frames is to suggest the nature of controversy as a spirit of an issue.

\section{Media framing and scientific application}

Media framing or its impact can be scientifically explained by observing such factors that can be categorized as predictors of response to both individual and group cognitive behaviour, for instance, events like Rohingya Crisis where the incidents would result in a kind of a social phobia that can be aggravated by wrong media framing through many factors like negative evaluation of the events, lack of information, anticipation of unknown to happen often resulting a kind of personality disorder. A scientific interpretation of such a crisis or event would often result in a social phobia that could be resolved only through therapeutic and scientific treatments commonly referred as Individual Cognitive Therapy (ICT) and Intensive Group Cognitive Therapy (IGCT). The treatment involves a scientist attempting to diagnose such predictors in the pathos or the emotional aspect of the victims. The signs of personality disorders are seen along with all such negative predictors that led to this social phobia (Mörtberg and Andersson, 2014).

In the light of social phobia resulting out of Rohingya like crises, it becomes ethically imperative for media framers to understand that 'framing effect' can influence decision-making. Emotions or 'pathos' play a major role in decision making when information found in the news media is sensitive and complex. For instance, media framers can portray the event in such a manner that it can either stimulate or stagnate the decision-making process as the 'framing effect' can highlight a particular aspect but eliminate the other. It can lead the readers to 
view the event only with a particular viewpoint, which can change the perception of the entire issue.

Scientifically, it can be proven with the fact that emotions that influence our decision making are deeply embedded in our brain, according to Benedetto De Martino, a cognitive neuroscientist at University College London. De Martino conducted an experiment on the brains of 20 volunteers. Prior to the experiment, half of the volunteers were exposed to framing effects and this group was told that it could affect the decision making. While the other half of volunteers were not given any advanced information about the ill effects of framing. This second group was thus susceptible to the impact of media framing. During the experiment, the scientists gave both groups a situation and offered them a few choices to make, which required each group to think of pros and cons before taking a decision. As expected, the first group that was made immune to the effects of media framing showed some activity in their brain region called the orbital and medial prefrontal cortex, which means that cognitively this group was stronger in controlling its emotions and impulses in decision making in a situation of crisis. On the contrary, the other group, which was more susceptible to the framing effect, showed a greater activity in their emotion and learning related brain region called the amygdala. In this group, according to the scientists, the brain areas were damaged by the framing scenario shared with them, which affected their emotional setup inside the brain, subsequently resulting in affecting their power of decision making behavior which was completely controlled by emotion and impulse. The above experiment also shows that some people think more rationally than others, which is the opposite of being impulsive or emotional. This experiment however does not presume that people who can think rationally have no emotions; in fact, every human being has emotions, but some people learn to cope up with their emotions. This experiment has proved this. Now it is important to see how emotions or pathos play further role in understanding a crisis, namely the Rohingya crisis chosen for this study.

\section{The Element of emotions and 'pathos,}

Framing typically focus on how people's viewpoints are influenced by "opposing ways of presenting, or framing, an issue or event" (Gross and D'Ambrosio, 2004). Media interpret and describe different political events by making use of frames in such a way that people can easily understand. Frames may be used in a biased way if necessary to details are omitted to present issues in a favorable or unfavorable way (Albrecht, 2009). Emotional framing has gained prominence in recent years (Nabi, 2003; Lu, 2015). The purpose of framing emotional appeals is to draw desired emotional reactions from the audience (Lu, 2015). Through the analysis of the Rohingya Muslim crisis, this study tends to evidence that "emotions serve as frames for issues, privileging certain information in terms of accessibility and thus guiding subsequent decision making" (Nabi, 2003). Studies on framing have largely focused on cognitive effects of framing while emotional effects have comparatively remained neglected (Gross, 2008). According to Entman (1993), while framing events "some aspects of perceived reality" are selected to represent them more saliently "in a communicating text in such a way as to promote a particular problem definition, causal interpretation, moral evaluation, and/or treatment recommendation".

For researchers to identify the framing of a particular issue in media content is to examine the framing devices employed such as words choices, specific arguments or descriptions. These conceivable devices point towards a main idea which constitutes as a part of a frame package. Hence, these devices are coherently structured together under a central theme which is the actual frame (Van Gorp, 2007). This study aims at exploring the emotional effects of the framing of Rohingya Muslim Crisis on the audiences by focusing on how the editors of Pakistani, British and US newspaper (Fig. 1) framed the events through use of the persuasive strategy of pathos (emotional appeals). The purpose of pathos, which the Greek philosopher Aristotle (1356/2006) referred to the appeals to emotions (anger, fear, confidence, pity), is to create an emotional response. Pathos, according to Aristotle, stirs emotions of readers and their judgments vary when they are happy, sad or hostile. Figure 1 indicates the research map for investigating media framing of the Rohingya Muslim crises.

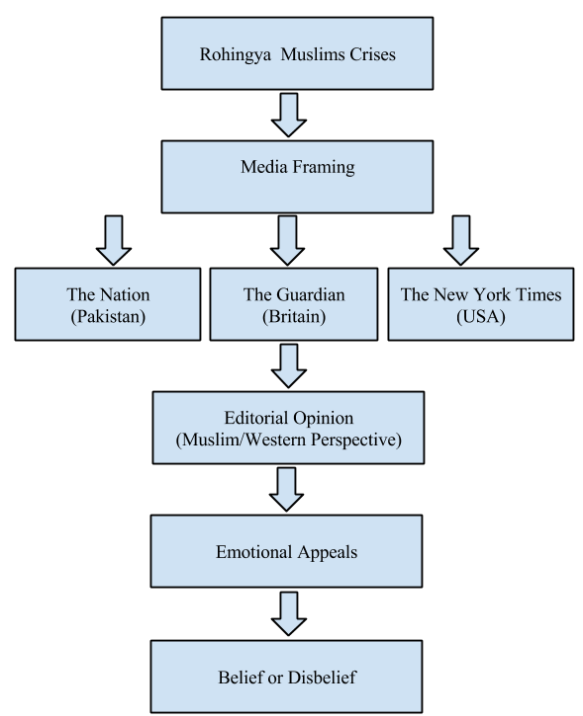

Fig. 1: Media framing of Rohingya Muslim crises

\section{Literature review}

This study examines framing of Rohingya Muslim crisis in Myanmar in international newspapers: Western (Britain and USA) and non-Western (Pakistan), a Muslim majority country. The purpose of this research paper is to investigate how the editorial opinion of the selected newspapers framed the issue to persuade the audience. The available 
literature suggests that the Rohingya crisis has been given scant attention from the perspectives of the newspaper editorials.

Among some of the existing studies, Letchamanan (2013) addressed the gap in education, discussed the teaching and learning provided to the Rohingya children in the refugee learning centers in Malaysia run by UNHCR and local NGOs and discussed the future of these children in Malaysia. The researcher conducted semi-structured interviews of the two principals and three teachers from the two learning centers namely Taiwan Buddhist Tzu-Chi Foundation in Kuala Lumpur and Rohingya Community School in Puchong. The study found that there exited a "huge gap" in the quality of education provided by these centers due to illequipped teaching and learning resources and incentives.

Robinson and Rahman (2012) examined the plight of the Rohingya people by presenting recent events and analysis of clashes between Muslims and Buddhists. The researcher addressed the question as who would take the responsibility of protecting the Rohingya community and put forward their recommendations to support and repatriate refugees in Bangladesh.

Drawing on the case of the Rohingya Muslims, Pugh (2013) conducted a genealogy of exclusion and illustrated that their status was not merely concerned with depriving od citizenship but it was actually implanted in the process of "nation building", "ethno-political identification", and "religious intolerance". The study challenged the centrality of the concept of legal citizenship through an investigation of Rohingya's exclusion such as from historical narratives, their ambiguous status along with socioeconomic uncertainty. It attempted to overstep the boundaries of the Rohingyas homelessness and lack of any official status in order to truly realize the nature of their marginalization.

Similarly, through another study, Rahman (2015) explored the causes of ethnic humanitarian vulnerability of the Rohingyas. The researcher used qualitative content analysis and the data were collected from secondary sources such as text books, journal articles, reports of government and nongovernment organizations, television and newspaper reports. The research reveals that the Rohingya people are the least wanted community and the most persecuted in the world as stateless refugees deprived of basic needs.

Azad and Jasmine (2013) also examined effectiveness of durability of traditional solutions offered by the UN refugee Agency (UNHCR) to the protracted Rohingya refugee situation in Bangladesh. The researcher argued that the solution of the Rohingya refugees rests on the political good will of all stakeholders (state parties) and the UN can play a vital role in applying coercive diplomacy through the Responsibility to Protect (global political commitment) to bar genocide and crimes against Burmese Muslims. The study discussed three durable solutions which have been implemented to end refugee crisis, namely, voluntary repatriation (not a viable option), local integration (unspoken reality) and resettlement (too little to count).

Through another study, Wagley (2014) established that the doctrine of the Responsibility to Protect was directly applicable to Burma's Muslim crisis following the institutionalized discrimination against Muslims which produced breach of justice. The study comprised two parts. In part one the researcher argued that since the Burmese government deliberately withheld justice against Rohingya victims an international system of justice under the UN's auspices should be implemented to independently investigate anti-Muslim violence. Part two examined the unwillingness demonstrated by the U.S. government in calling for an international investigation. It was argued that under its engagement policy in Burma the U.S. gave a secondary importance to anti-Muslim violence and hardly encouraged the Burmese government to redress the Muslim crises.

The Rohingya refugees issue in Bangladesh was investigated by Al Imran and Mian (2014). The researchers discussed in detail the issue of refugees in the country and highlighted the problems caused by Rohingya such as threat to national security of Bangladesh. The paper also shed light on role of constitutional provisions, judiciary and state policy in relation to asylum seekers or refugees. It advocated that strict national or domestic laws should be enacted to deal with the influx of refugees.

Abdelkader's research (2014) also focused on the Rohingya Muslim crisis. The research examined the Rohingya Muslim experience historically as well as through humanitarian lens. The paper analyzed human rights abuses committed against the Rohingya Muslims and contemporary developments. Some of the major human rights concerns analyzed included: Burmese denial of citizenship, restricted religious freedom, forced displacement and lethal use of force. The researcher also discussed several realities surrounding the US policy related to Myanmar.

Likewise, another study by Parnini et al. (2013) also investigated the Rohingya refugee crisis and the relations between Bangladesh and Myanmar. The researchers discussed human rights violation against Rohingya Muslims, their act of taking refuge in Bangladesh and the Rohingyas and BangladeshMyanmar relations. The researchers also advocated the need for bilateral discussion and negotiations which can facilitate the process of democratization in Myanmar.

Southwick (2015) also voiced solutions for the prolonged plight of the Rohingya Muslims minority and highlighted the human rights violation and discrimination against the Muslims. The researcher argued that why the possibility of genocide has been raised against this minority group and pointed out the international weakness in addressing crises. The article emphasized that international community is legally bound to act to protect the rights of Rohingyas. 
Crossman (2014) analyzed human rights violations against the Rohingya Muslim minority by the majority Buddhist Rakhine population supported by the central government. The researcher examined ethnic genocide of Rohingya Muslims, government policies from 2000-2014 targeting Rohingyas and political, economic and sociocultural chauvinism which rendered them stateless. The article also calls into question the inability of international community such as USA, EU and ASEAN to cease the abuse of Rohingya Muslims under the under the Responsibility to Protect doctrine. It also recommended peace building plan for the ending the crises and stressed reconciliations between Buddhists' population and its diverse ethnic and religious minorities.

Biver (2014) investigated the role and power of Buddhism in reference to Burmese nationalism. The researcher highlighted the role of religion in nationalist undertakings in the case of Myanmar. The relied on narrative analysis of reports from NGOs, articles from newspapers, academic writings and second-hand interviews. The researcher concluded that the religion Buddhism itself did not cause anti-Muslim propagations and inter-religious conflicts. Rather, the practice of its teachings and symbolic representations by monkhood in Burma and state advocated so to attain legitimacy and justify passionate discourses and actions.

Jahan (2014) conducted a sociological analysis of rights of Rohingya refugee children in Bangladesh and explored the national crisis faced by the Rohingyas Muslim community. The researcher relied on the responses of 100 refugees selected from the camp sites in Bangladesh. It was concluded that Rohingya refugees and children in particular were deprived of rights, in camps, necessary for human beings to live such as healthcare and education.

The review of the past studies indicates that media framing of Rohingya Muslims crises have been ignored by large. Therefore, this study examines how the mainstream newspapers portrayed the issue.

\section{Data collection and data analysis}

The data for this research paper consisted of three English language newspaper editorials sampled from the Pakistani (The Nation), American (The New York Times) and British (The Guardian) mainstream newspapers which disseminated opinion about the Rohingya Muslim crises in Burma (Table 1). This particular selection of the three different newspapers from three different countries meant to investigate how the Buddhists/Brumes government's treatment of Rohingya crisis was portrayed by the mainstream English language newspapers in a Muslim majority country (Pakistan) and outside the Muslim world by Western media (Britain, USA). It tends to explore how the editorial opinions of Pakistani, American and British newspapers Rohingya narrated the Rohingya Muslim crisis and to what extent they kept the audience closer to the events by appealing to emotions. This paper utilizes content analysis, the widely used qualitative research approach to interpret the meaning (Hsieh and Shannon, 2005) of editorial texts. The technique has been found reliable in examining various trends as well as different patterns in documents such as the newspaper editorials in our case (Stemler, 2001).

Table 1: Newspapers' profile

\begin{tabular}{|c|c|c|c|}
\hline Name & Country & Dampled Editorial \\
\hline The Nation & Pakistan & Legitimising Racism & March 27, 2016 \\
\hline The Guardian & Britain & $\begin{array}{c}\text { The Guardian view on the Rohingya refugee crisis : cruel } \\
\text { and stupid }\end{array}$ & May 15, 2015 \\
\hline The New York Times & USA & $\begin{array}{c}\text { Ending the Horror of Myanmar's } \\
\text { Abuse of Muslims }\end{array}$ & January 25, 2016 \\
\hline
\end{tabular}

The Nation is an English language daily newspaper published in three different stations in Pakistan. The newspaper is part of the Nawaiwaqat Group founded in 1940 by Hamid Nizami. The paper thus belongs to the oldest media group in Pakistan. It claims to be one of the most internationally quoted Pakistani newspapers. The newspaper provides separate sections for national and foreign news coverage of the events. The daily claims to have boldest and influential editorials in the country with a variety of opinion on various national and international issues (The Nation, 2016). The newspaper has attracted several research scholars for its editorial opinion on different issues. (Ayoub and Ahmed, 2013; Shabir et al., 2014; Tabassum et al., 2013).

The Guardian is influential English language daily newspaper which is published in London. It is considered one of the leading papers in the United Kingdom. The newspaper was founded in Manchester in 1821. The newspaper has been historically admired for its special interest in investigative journalism, its literary criticism and its dispassionate discussions of different subjects. The daily has also been well known for its foreign correspondence, comparatively less conservative editorial staff and more independent reporting. The paper is owned by the Scott Trust, the owner of Guardian Media Group (Luebering, 2011). The editorial stances of the newspaper on various international issues have been the focus of research scholars for exploring different events (Atai and Mozaheb, 2013; Healy, 2011; Shabir and Iqbal, 2010; Van Dijk, 1989)

The New York Times is daily English Language newspaper published in New York City. It is one of 
the world's renowned newspapers with its editorial excellence and a newspaper of record in the United States. The newspaper was established in 1851 with a policy of avoiding sensationalism and restraining to objective reporting. The paper gained an early success as its editorial pattern attracted learned and intellectual readership. The newspaper's coverage of the two world wars enhanced its reputation for excellence in disseminating world news. In the 1970s, the newspaper introduced a national edition broadcast by satellite. The newspaper pays attention to full reporting of the day stories and maintains a good coverage of international news (Tikkanen, 2015). Like the other selected Pakistan and British newspapers, the editorial stands points of The New York Times have also been analyzed for their opinion on international issues (Izadi and Saghaye-Biria, 2007; Jahedi and Abdullah, 2012; Yousaf and Ali, 2012).

\section{Research question}

This paper answers the following research question: How do the Pakistani, British and American mainstream English language newspapers frame the Rohingya Muslim crises?

\section{Analysis: Framing of Rohingya Muslims}

This section represents the analysis of the Rohingya Muslims crises by the following three selected newspapers:

\subsection{The Nation}

Our findings of the Rohingya Muslim crises as framed by The Nation of Pakistan confirmed that the newspaper criticized the Nobel laureate Aung San Suu Kyi, a Burmese statesperson and State Counselor of Myanmar, for expressing her dislike at giving interview to a Muslim. The paper accused her of legitimizing racism in doing so. The newspaper stirred the readers' emotions by framing that such a bigoted opinion was not so unpleasant rather what mattered was that such type of discriminatory remarks were uttered by a person who has been heralded as a progressive liberal across the world. She has been further blamed for showing indifference in dealing with the plight of Rohingya Muslims, displaying refusal in giving statements in their favor and showing solidarity with them. An emotional appeal was also created through the argument that Aung San Suu Kyi even refused to accept the reports from the Human Rights Watch organizations which pointed at the Buddhists in the Arakan [Rakhine] state for persecuting Muslims, which evidenced that as leader she overlooked the way a minority [Muslims] is being marginalized. The editorial pathos through the discourse strategy of comparison draws the world's attention to the neglected crisis of Rohingya Muslim by arguing that it should be universally condemned, just like attacks in Brussels or Paris have been denounced by all and sundry.

Through another emotional framing, the paper emphasizes that what was happening in Myanmar was about human lives whether they were Rohingya Muslim or anyone else. Here, we get the impression that the newspaper asserts in resolving the Rohingya crisis on humanitarian grounds and not necessarily on the basis Muslim ethnicity. The editorial makes use of number technique to evoke the desired emotional response from the audience through the opinion that over 140000 Muslims have been displaced since hatred against them began to spread in Burma. Similarly, we as readers are informed that the Burmese government remained silent on the Rohingya Muslim crisis and what was expected from Aung San Suu Kyi, the Nobel Peace Prize winner for human rights struggle, seemed not likely to bring change even after her ascent to Minister in the new cabinet. The newspaper warned of serious consequences if such hatred continued along ethnic, racial or religious lines. The editorial ends with a positive advice that international community should realize the damage caused by divisive politics and abandon it for the common good.

\subsection{The Guardian}

Following the editorial point of view the Pakistani newspaper, The Guardian editors also relied on several emotional appeals (pathos) to frame the Rohingya Muslim crises. In targeting the readers' emotions, the paper claimed that Burma has unleashed an anti-Muslim chauvinism within its Buddhist majority. Through another emotional appeal, the paper sympathizes with the plight of Rohingya Muslim refugees. They have been portrayed as drifting without succor in the Andaman Sea appallingly. The newspaper convinces the audience that troubles of the Rohingya Muslims must be alleviated. The newspaper has lexically defined the Rohingya Muslims as unfortunate people to earn international concern and remind the world of its humanitarian duty. There has been positive framing of the Muslims' demands to become naturalized citizens of Myanmar through the editorial emphasis of citing numbers that their families had lived in Burma for more than 60 years. In addition, it has been claimed that Rohingya Muslims were also denied the right to vote. The paper rejects resettlement plan for the minority by declaring it cruel and on the basis of proposition that it caused displacement of hundreds of thousands.

The editorial writers create another, appeal, to make the readers identify with the Rohingya Muslims, that Burmese government practiced a draconian formula which historically proved ludicrous and vicious in dealing with minority's crises. Similarly, the enforced migration of the Rohingyas through dreadful journey at sea was narrated as a tragedy by the newspaper and the stay of others has been shared as hopelessly trapped in camps and desperation of families. In favor of the 
Rohingyas, the editorial pointed out that their crises must be dealt with fairly and all types of impartial assessment must be firmly excluded. The editorial ended with the declaration of terming the crises a sad paradox: Burma moving towards to democratization but the same time developed a popular anti-Muslim chauvinism. As another instance of emotional frames, the newspaper labeled the issues cruel and stupid and it insists that Burmese government must face down this chauvinism and amend its policy towards the Muslim ethnic minority.

\subsection{The New York Times}

Another Western point of view, based on the deliberate selection of The New York Times, has also framed several emotional scenes and kept readers on the side of the Rohingya Muslims and against the Burmese regime mainly the Buddhist majority rule. The newspaper declares that the government of Myanmar committed abuse of Muslims in dealing with the crises and such a horror must be ceased immediately. As examined, the editorial pathos persuades the readers that Myanmar's authorities have overseen the systematic persecution of the country's Rohingya Muslim minority. The newspaper constantly framed the anti-Muslims actions and seemingly intended to evoke emotional responses from the readership. To illustrate, the editorial claims that the Myanmar authorities approved bills which regulated interfaith marriage, birth spacing and religious conversion to intentionally target the Myanmar's Muslim minority. In comparison with the editorial stand point of the Pakistani and British newspaper, the US newspaper also framed that Rohingyas were stripped of their citizenship rights, forced to live in concentration camps with inadequate facilities and were even deprived of medical care, jobs and even food, and held prisoners in villages.

Another emotional appeal is framed through the opinion that Rohingya crises became a human rights debacle due to scenes of genocide committed during it. Meanwhile, some Rohingya Muslims were forced to risk their lives at the hands of criminal syndicates and trafficked to Malaysia and Bangladesh or even forced them into servitude on finishing boats. Like The Nation of Pakistan, the newspaper accused Aung San Suu Kyi for stubbornly remaining silent on the fate of Muslims. The newspaper claims that such an act evidenced that an anti-Muslim sentiment had been lashed to a fever pitch even among the political elites of the country of which Aung San Suu Kyi was a part. The media of framing by the US newspaper apparently held the Rohingya's terrible plight. The editorial voice insists on ending such a plight and redressing discrimination unleashed against Myanmar's Muslims. The editorial ends by framing another emotional appeal that military regime of Burma must end abuses and seeks an end to all discriminatory laws including hateful speeches and crimes toward religious minorities.

\section{Discussion}

The results about the portrayal of the Rohingya Muslim crisis confirm that mainstream newspapers in Pakistan, Britain and USA played a significant role in framing the issue. The newspapers have seriously evaluated the plight of homeless and displaced Rohingya Muslims and their social persecution at national level. The editorial staff of the selected newspapers has adopted a similar stance in representing the crisis, i.e. pro-Rohingya Muslim monitory, anti-Buddhist majority anti- Myanmar ruling elite. Moreover, the similarity of the assumed Western and non-Western perspective makes us belief that the Rohingya Muslim community was rightful in its demand of getting naturalized and acquiring citizenship in Myanmar. On the contrary, the ruling elite of Myanmar is severely criticized for harshly treating Rohingya Muslims, accused of neglecting this ethnic minority and depriving them of even the basic rights to live as human beings. The newspapers frequently framed emotional appeals to withhold the readers' attention and interest in crises. The findings lead us to the conclusion that framing emotional appeals become "an effective approach in promoting information seeking and policy support" and redefine the much argued relationship between emotions and persuasion (Lu, 2016). The study of Rohingya Muslim crises also conform to the notion that in framing news stories, such as the selected editorial narrations of Pakistani, British and US newspapers, emotions are employed "to capture attention, influence attitude and affect behavior" (Nabi, 2003). Through such framing techniques, the newspapers have succeeded in convincing the readers to show their sympathies for the Rohingya minority in particular and have highlighted the crisis on international level in general.

\section{Conclusion and Recommendation}

Rohingya crisis has appealed to the emotions of all Muslims and non-Muslims worldwide. This study focused on how the two media perspectives (Western/non-Western) framed the Rohingya Muslim crises by appealing to the readers' emotions. The focus in this paper was on framing in a news room and its internal factors. These include issues of editorial policies and news values. It has significantly covered the existing gap on the Rohingya crises which has been paid little attention from the perspective of the newspaper editorials and has thus evidenced how media framing through emotional appeals promoted the cause of Rohingyas. However, another objective of this research was to study the scientific principles underlying media framing as discussed in the context of neurocognitive contexts and its impact on individual and group decision making. The results of this paper will enrich the knowledge about media framing and the resultant neurocognitive behaviors and its impact on a person's emotions as it has been 
attempted to show in the case of the Rohingyas crisis. The future research will hopefully adopt the findings of this research on a wider scale in their application of media framing principles to portray different issues.

Future research is recommended to apply the scientific principles of neurocognitive sciences in similar incidents and determine different versions in the portrayal of the same crisis. Also, a comparative study can be carried out of the coverage of Rohingya Muslims by the state-owned media newspaper in Myanmar and some other international news media coverage to explore the influence of media groups' political and social orientations in covering controversial issues. Similarly, future studies can also be conducted to examine ideological portrayal of Rohingya crisis actors: Muslim minority vs. Buddhists majority in a more detailed way and by selecting different newspapers.

\section{References}

Abdelkader E (2014). The Rohingya Muslims in Myanmar: Past, present, and future. Oregon Review of International Law, 15(3): 393-412.

Al Imran HF and Mian N (2014). The Rohingya refugees in Bangladesh: A vulnerable group in law and policy. Journal of Studies in Social Sciences, 8(2): 226-253.

Albrecht MD (2009). The plame game: Framing a political scandal. M.Sc. Thesis, Louisiana State University, Baton Rouge, Louisiana.

Aristotle $O$ (2006). On rhetoric: A theory of civic discourse. 2nd Edition, Oxford University Press, Oxford, UK.

Atai MR and Mozaheb MA (2013). The representation of Iran's nuclear program in British newspaper editorials: A critical discourse analytic perspective. International Journal of Society, Culture and Language, 1(2): 15-33.

Ayoub U and Ahmed T (2013). Portrayal of PakistanUSA relationship with reference to drone strikes on Waziristan in the editorials of Dawn and Nation: A comparative study. Academic Research International, 4(6): 56-64.

Azad A and Jasmine F (2013). Durable solutions to the protracted refugee situation: The case of Rohingyas in Bangladesh. Journal of Indian Research, 1(4): 25-35.

Biver E (2014). Religious nationalism: Myanmar and the role of Buddhism in anti-Muslim narratives. M.Sc. Thesis, Lund, Lund University, Sweden.

Chong D and Druckman JN (2007). A theory of framing and opinion formation in competitive elite environments. Journal of Communication, 57(1): 99-118.

Chong D and Druckman JN (2007). Framing theory. Annual Review of Political Science, 10: 103-126.
Chyi HI and McCombs M (2004). Media salience and the process of framing: Coverage of the Columbine school shootings. Journalism and Mass Communication Quarterly, 81(1): 22-35.

Crossman L (2014). Myanmar's Rohingya refugees: The search for human security. M.Sc. Thesis, Georgetown University, Washington DC, USA.

De Vreese CH (2003). Framing: Theory and typology. In: Lagerwerf L, Spooren W and Degand L (Eds.), Determination of information and tenor in texts: Multidisciplinary approaches to discourse. Neerlandistiek Publikationen, Amsterdam, Netherland: 151-164.

De Vreese CH (2005). News framing: Theory and typology. Information Design Journal+Document Design, 13(1): 51-62.

De Vreese CH, Peter J and Semetko HA (2001). Framing politics at the launch of the euro: A cross-national comparative study of frames in the news. Political Communication, 18(2): 107-122.

Dewulf A, Gray B, Putnam L, Lewicki R, Aarts N, Bouwen R and Van Woerkum C (2009). Disentangling approaches to framing in conflict and negotiation research: A meta-paradigmatic perspective. Human Relations, 62(2): 155-193.

Entman RM (1993).Framing: Toward clarification of a fractured paradigm. Journal of Communication, 43(4): 51-58.

Entman RM (2004). Projects of power: Framing news, public opinion, and U.S. foreign policy. University of Chicago Press, Chicago, USA.

Gross K (2008). Framing persuasive appeals: Episodic and thematic framing, emotional response, and policy opinion. Political Psychology, 29 (2): 169-192.

Gross K and D'Ambrosio L (2004). Framing emotional response. Political Psychology, 25(1): 1-29.

Healy D (2011). Ideologies and us versus them: A comparative study using systemic functional grammar of Irish and British editorials related to the ending of the IRA's armed campaign. M.Sc. Thesis, University of Birmingham, Birmingham, UK.

Hsieh HF and Shannon SE (2005). Three approaches to qualitative content analysis. Qualitative Health Research, 15(9): 1277-1288.

International Crisis Group (2014). Myanmar: The politics of Rakhine state (Asia Report N 261). Available online at: http://www.burmalibrary .org/docs19/ICG-myanmar-the-politics-ofrakhine-state-red.pdf

Izadi F and Saghaye-Biria H (2007). A discourse analysis of elite American newspaper editorials: The case of Iran's nuclear program. Journal of Communication Inquiry, 31(2): 140-165. 
Jahan I (2014). Nationality crisis and rights of Rohingya refugee children: A sociological analysis of children's rights in Bangladesh. M.Sc. Thesis, University of Dhaka, Dhaka, Bangladesh.

Jahedi M and Abdullah FS (2012). Post-September 11 discourse: The case of Iran in The New York Times. International Journal of English Linguistics, 2(1): 59-70.

Lecheler S, Schuck ART and de Vreese CH (2013). Dealing with feeling: Positive and negative discrete emotions as mediators of news framing effects. Communications: The European Journal of Communication, 38(2): 189-209.

Lecheler SK (2010). Framing politics. Ph.D. dissertation, University of Amsterdam, Amsterdam, Netherlands.

Letchamanan H (2013). Myanmar's Rohingya refugees in Malaysia: Education and the way forward. Journal of International and Comparative Education, 2(2): 86-97.

Lu H (2015). The effects of emotional appeals and gain versus loss framing in communicating sea star wasting disease. Science Communication, 38(2): 143-169.

Luebering JE (2011). The Guardian. In Encyclopedia Britannica Online. Available online at: https://global.britannica.com/topic/The-Guardia n-British-newspaper

Mörtberg E and Andersson G (2014). Predictors of response to individual and group cognitive behaviour therapy of social phobia. Psychology and Psychotherapy: Theory, Research and Practice, 87(1): 32-43.

Nabi RL (2003). Exploring the framing effects of emotion: Do discrete emotions differentially influence information accessibility, information seeking, and policy preference?. Communication Research, 30 (2): 224-247.

Parnini SN, Othman MR and Ghazali AS (2013). The Rohingya refugee crisis and BangladeshMyanmar relations. Asian and Pacific Migration Journal, 22(1): 133-146.

Pugh CL (2013). Is citizenship the answer?: Constructions of belonging and exclusion for the stateless Rohingya of Burma. Available online at: http://www.imi.ox.ac.uk/pdfs/wp/wp-76-13.pdf

Rahman KA (2015). Ethno-political conflict: The Rohingya vulnerability in Myanmar. International Journal of Humanities and Social Science Studies, 2(1): 288-295.

Robinson IG and Rahman IS (2012). The unknown fate of the stateless Rohingya. Oxford Monitor of Forced Migration, 2(2): 16-20.

Scheufele B (2004). Framing-effects approach: A theoretical and methodological critique. Communications, 29(4): 401-428.
Scheufele DA and Tewksbury D (2007). Framing, agenda setting, and priming: The evolution of three media effects models. Journal of Communication, 57(1): 9-20.

Shabir G and Iqbal Z (2010). Media construction of Pakistan's image: Discourse analysis of editorials of the elite UK newspapers. China Media Research, 6 (3): 48-56.

Shabir G, Khan AW, Adnan M and Safdar G (2014). A comparative analysis of the editorials of The Nation and The News: The case study of PakIndia relations issues (2008-2010). Journal of Political Studies, 21(1): 41-59.

Shah DV, Watts MD, Domke D and Fan DP (2002). News framing and cueing of issue regimes: Explaining Clinton's public approval in spite of scandal. Public Opinion Quarterly, 66(3): 339370.

Shmueli D, Elliott M and Kaufman S (2006). Frame changes and the management of intractable conflicts. Conflict Resolution Quarterly, 24 (2): 207-218.

Southwick K (2015). Preventing mass atrocities against the stateless Rohingya in Myanmar: A call for solutions. Journal of International Affairs, 68(2): 137-156.

Stemler S (2001). An overview of content analysis. Practical Assessment, Research and Evaluation, 7(17): 137-146.

Tabassum M, Shah SK and Bilal M (2013). A critical discourse analysis of the left and right wing ideologies in Pakistani English newspaper editorials. Journal of Education and Practice, 4(13): 72-78

Tankard JW (2001). The empirical approach to the study of media framing. In: Reese SD, Gandy Jr $\mathrm{OH}$ and Grant AE (Eds.), Framing public life perspectives on media and our understanding of the social world. Mahwah, Lawrence Erlbaum Associates, New Jersey, USA: 95-106

The Nation (2016). About us. Available online at: http://nation.com.pk/about-us.html

Tikkanen A (2015). The New York Time. In Encyclopedia Britannica Online. Available online at: https://global.britannica.com/topic/ TheNew-York-Times

Van Dijk TA (1989). Race, riots and the press: An analysis of editorials in the British press about the 1985 disorders. International Communication Gazette, 43(3): 229-253.

Van Gorp B (2007). The constructionist approach to framing: Bringing culture back in. Journal of Communication, 57(1): 60-78.

Wagley R (2014). Quiet audience: US responsibility to call for an international investigation into 
crimes against Muslims in Burma. Emory International Law Review, 28: 43-61.

Yousaf Z and Ali E (2012). Coverage of Pak-US relations in elite press of Pakistan and US during the democratic government of Pakistan People's Party; March 2008 to February 2012 (media and foreign policy perspective). IOSR Journal of Humanities and Social Science, 6(1): 22-33. 